\title{
Use of RAPD assay for the detection of mutation changes in plant DNA induced by UV-B and $\gamma$-rays Oksana Danylchenko* and Boris Sorochinsky
}

\author{
Address: Department of Plant Biophysics and Radiobiology, Institute of Cell Biology and Genetic Engineering, acad. Zabolotnogo, 148, Kiev, \\ 03143, Ukraine \\ Email: Oksana Danylchenko* - oksanaukr@yahoo.com \\ * Corresponding author
}

from Cell Biology of Nitric Oxide and Cell Death in Plants

Yalta, Ukraine, 8-II September 2004

Published: 3I May 2005

BMC Plant Biology 2005, 5(Suppl I):S9 doi:I0.I I86/I47I-2229-5-SI-S9

\section{Background}

RAPD (random amplified polymorphic DNA) analysis is wide used for the genetic mapping, taxonomic and phylogenetic studies of many organisms. It can be also applicable for the detection of DNA alterations after influence of many genotoxical agents as well [1]. UV-radiation can produce several major types of DNA lesions such as cyclobutane-type pirimidine dimers and the 6-4 photoproducts [2]. Another important types of DNA damages such as protein cross-links, DNA strand breaks, deletion or insertion of base pairs can also be induced by UV-irradiation. Whereas, irradiation by $\gamma$-rays leads to the increasing level of DNA break formation. These different types of DNA damages must be detected by changes in RAPD profiles. The aim of present study was to investigate the possibility mutation changes in plant DNA after the influence of UV-B and $\gamma$-ray with using RAPD method. The 10-mer primers with single nucleotide substitutions were used in order to estimate these structural alterations in DNA following after genotoxical agents' treatment.

\section{Materials and methods}

Approximately $0.20 \mathrm{~g}$ of plant tissue from alfalfa seedlings, which was irradiated by high doses of UV-B and $\gamma-$ ray $\left(\mathrm{LD}_{50}\right)$ was frozen in liquid nitrogen, ground with mortar and pestle and incubated in $1.5 \mathrm{ml}$ of extraction buffer $(100 \mathrm{mM}$ Tris-HCl pH 8, $100 \mathrm{mM} \mathrm{NaCl}, 50 \mathrm{mM}$ EDTA $\mathrm{pH} 8,2 \%$ SDS and $0.1 \mathrm{mg} / \mathrm{ml}$ proteinase $\mathrm{K}$ ) during $1.5 \mathrm{~h}$ at $37^{\circ} \mathrm{C}$. DNA was extracted twice with chloroform:isoamyl alcohol (24:1) mixture. DNA was precipitated from the aqueous phase with 2 vol. of cold isopropanol at $-20^{\circ} \mathrm{C}$ during $48 \mathrm{~h}$. DNA pellet was harvested by centrifugation, washed several times in $70^{\circ} \mathrm{eth}-$ anol, air-dried and dissolved in deionized water. RNAse treatment was performed accordingly to [3]. DNA was analyzed using agarose gel electrophoresis.

RAPD amplification involved initial denaturation of DNA template (20 ng per $25 \mu \mathrm{l}$ reaction mix) at $94^{\circ} \mathrm{C}$ for $3 \mathrm{~min}$, followed by 33 cycles of $1 \mathrm{~min}$ at $94^{\circ} \mathrm{C}, 1 \mathrm{~min}$ at $36^{\circ} \mathrm{C}$ and $2 \mathrm{~min}$ at $72^{\circ} \mathrm{C}$ in thermocycler "Tertsik" (Russia). Amplification was finished with incubation at $72^{\circ} \mathrm{C}$ for 7 min. The sequences of 10-mer primers (MedBioservice) with single base substitutions are given in Table 1 .

PCR amplification products were analyzed in $2.5 \%(\mathrm{w} / \mathrm{v})$ agarose gel in $0.5 x T B E$ buffer. PCR products $(25 \mu \mathrm{l}$ per sample) were mixed with 3-5 $\mu \mathrm{l} \mathrm{Gel} \mathrm{Loading} \mathrm{Dye} \mathrm{Solu-}$ tion (Fermentas, Lithvuania) and loaded onto the agarose gel, containing ethidium bromide $(0.5 \mathrm{mkg} / \mathrm{ml})$. Gene Ruler 100 bp DNA ladder was used for each agarose gel. Electrophoresis was carried out at $80 \mathrm{~V}$ for $3.5 \mathrm{~h}$, then the results were visualized under UV light and documented using Canon digital camera.

Table I: Sequences of the 10-mer primers (5'-3') used in experiments

\begin{tabular}{ll}
\hline Primer & Sequence \\
\hline OPB 8 & GTCCACACGG \\
OPB 8-1 & GACCACACGG \\
OPB 8-2 & GTGCACACGG \\
OPB 8-3 & GTCGACACGG \\
OPB-8-4 & GTCCTCACGG \\
\hline
\end{tabular}




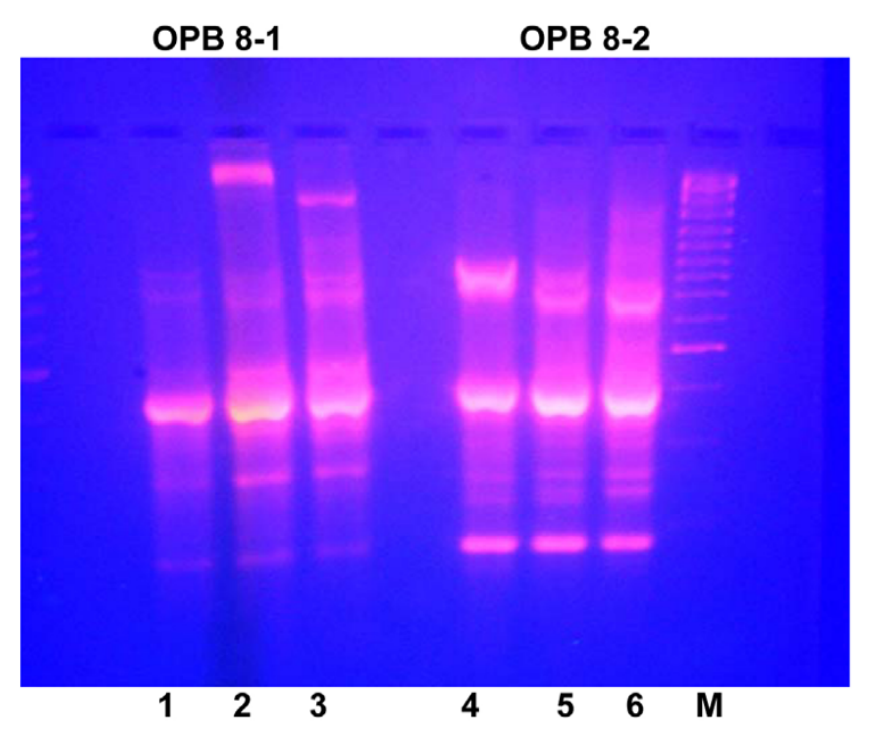

Figure I

Effect of single nucleotide substitutions in 10-mer primers (OPB 8-I, OPB 8-2) on RAPD profile ( $\mathbf{M}$ - Gene Ruler 100 bp DNA Ladder): I, 4 - unirradiated control; 2, 5 - $\gamma$-irradiation; 3, 6 - UV-B

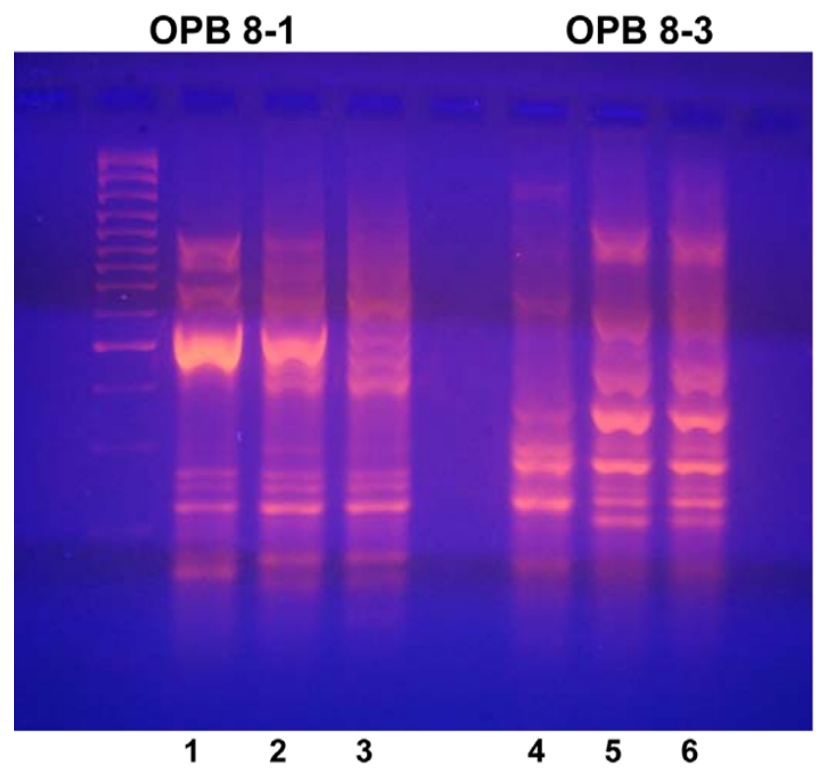

Figure 2

Effect of single nucleotide substitutions in 10-mer primers (OPB 8-I, OPB 8-3) on RAPD profile ( $\mathbf{M}$ - Gene Ruler 100 bp DNA Ladder): I, 4 - unirradiated control; 2, 5 - $\gamma$-irradiation; 3, 6 - UV-B

\section{Results}

It was shown, that single nucleotide substitutions in 10mer primers indeed can be reflected on the amplicons' profiles. The main changes observed in the RAPD profiles have been resulted both in an appearance (see Figure 1) or disappearance of different bands (see Figure 2) with variation of their intensity as well. These effects might be connected with structural rearrangements in DNA caused by different types of DNA damages.

\section{Conclusion}

Thus, RFLP method is applicable for the detection of changes in the DNA structure after different genotoxical treatments. The variation in band intensity and disappearance of some bands may correlate with level of photoproducts in DNA template after genotoxical treatment, which can reduce the number of binding sites for Taq polymerase. Appearance of new bands can be explained as the result of different DNA structural changes (breaks, transpositions, deletions etc). We can estimate the existence of mutation and structural alterations in plant DNA after impact of different stressful factors on the bases of DNA patterns obtained after RAPD with the set of primers. Obviously, sensitivity of the RAPD assay depends of the mutations level and it needs further investigations.

\section{References}

I. Atienzar F, et al.: Evaluation of the RAPD assay for detection of DNA damage and mutations. Mut Res 2002, 521:151-163.

2. Hollosy F: Effects of ultraviolet radiation on plant cells. Micron 2002, 33:179-197.

3. Draper J, Scott R: Plant genetic transformation and gene expression. Moscow: Mir Publ (in Russ); 1991.

Publish with Biomed Central and every scientist can read your work free of charge

"BioMed Central will be the most significant development for disseminating the results of biomedical research in our lifetime." Sir Paul Nurse, Cancer Research UK

Your research papers will be:

- available free of charge to the entire biomedical community

- peer reviewed and published immediately upon acceptance

- cited in PubMed and archived on PubMed Central

- yours - you keep the copyright
BioMedcentral 